несомненно, способствуют развитию творческого потенциала студентов высших учебных заведений Германии. Существенное значение в этой работе имеют выделенные выше формы работы с младшими научными кадрами, в частности, организация летних научных школ, конференции идей, междисциплинарных коллоквиумов, класса мастеров; научное сотрудничество высших учебных заведений Германии с научными объединениями промышленности (временные исследовательские группы, консультативные центры, комплексы, работа в научных комиссиях, методико-диагностические центры). Дальнейшие исследования будут направлены на определение содержания управления НИДС на различных образовательных уровнях.

\title{
Литература
}

1. Кравченко Т. А. Исследовательская деятельность в университетах Германии / Т. А. Кравченко // Исследовательская деятельность в вузовской и послевузовской подготовке бакалавров, магистров, аспирантов / Под ред. И.А. Зимней. - М. : МИСиС, 2010. - 220 с. 2. Покладок Е. Б. Совершенствование подготовки научноисследовательских кадров в Германии и Франции / Е. Б. Покладок, О. П. Выражейкина. - М. : МИСиС, 2009. - 260 с. 3. Радионова С. А. Содержание и технологии организации исследовательской деятельности студентов педагогических учебных заведений стран Евросоюза: автореф. дисс. на соискание ученой степени канд. пед. наук: спец. 13.00.01 «Общая педагогика и история педагогики»/ С. А. Радионова. - Казань, 2006. - 20 с. 4. Ратнер Ф. Л. Научная деятельность студентов Германии / Ф. Л. Ратнер. - Казань: Казанский университет, 1992. - 180 с. 5. Ульмер С. Анализ преподавания и взаимоотношений между преподавателями и студентами / С. Ульмер // Высшее образование в Европе. - 1987. - Т. XII. - №4. C. 45-49. 6. Graf W. Die Anleitung des Selbstudiums / W. Graf. - Humboldt-Universität zu Berlin, 2011. - $80 \mathrm{~s}$. 7. Hermann G. Spezifische Merkmale einer Sektionsleistungsschau / G. Hermann, M. Widmann // Das Hochschulwesen. - 1994. № 8. - S. 214-215. 8. Kessler W. Zur Entwicklung von Nachwuchswissenschaften im Proze $\beta$ des Forschungsstudiums-eine hoch schul pädagogische Untersuchung der Studenten / W. Kessler. - Halle : Martin-Luther-Universität, 1999. - №1 0. - S. 3-12. 9. Kiel S. Der Hochschullehrer als Betreuer/ S. Kiel. - Berlin : Deutscher Verlag der Wissenschaften, 1987. - 155 s. 10. Knöchel W. Einführung in die Hochschule Pädagogik. Teil 2. / W. Knöchel., F. Lichtenecker, R. Retzke. - Berlin, 1986. - $243 \mathrm{~s}$. 11. Melhorn H. G. Erziehung rum Schopfertum / H. G. Melhorn // Das Hochschulwesen. 1980. - № 6. - S. 177-181. 12. Wissenschaft and neues Weltbild. Vorlesungen / Hrsg. von H. Grabes. Gissen: verlag der Ferberschen Universitatsbuchhandlung, 1999. - 272 s.

УДК 372.48:373.1(477)

Володимир Бугрій

\section{ВИКОРИСТАННЯ КРАЕЗНАВСТВА ЯК ЗАСОБУ ВДОСКОНАЛЕННЯ ФОРМ НАВЧАННЯ ІСТОРІЇ У ШКОЛІ (30-50-ТІ РР. ХХ СТ.)}

Бугрій В. С. Використання краєнавства як засобу вдосконалення форм навчання історії у школі (30-50-ті рр. ХХ ст.).

У статті проаналізовано практику використання краєзнавства як засобу вдосконалення форм навчання історії у школі у 30-50-ті рр. ХХ ст. 3'ясовано, що використання краєзнавчого матеріалу сприяло урізноманітненню видів уроку, активізації пізнавальної діяльності учнів, збільшенню обсягу самостійної роботи школярів, посиленню зв'язків курсу історії 3 іншими предметами. Установлено, що краєзнавчий 
матеріал на уроках історії використовувався не лише для розв'язання навчальних, а й ідейно-виховних завдань. Розглянуто, як у досліджуваний період пропагувався досвід використання краєзнавства в навчанні історії.

Ключові слова: форми навчання історії, урок, історичне краєзнавство, загальноосвітня школа, пізнавальна діяльність учнів.

Бугрий В. С. Использование краеведения как средства усовершенствования форм обучения истории в школе (30-50-е гг. ХХ ст.).

В статье проанализировано практику использования краеведения как средства усовершенствования форм обучения истории в школе в 30-50-е гг. XX ст. Установлено, что использование креведческого материала способствовало проведению разных видов урока, активизации познавательной деятельности учащихся, увеличению объема самостоятельной работы школьников, усилению связей курса истории с другими предметами. Выявлено, что краеведческий материал на уроках истории использовался не только для решения учебных, но и идейновоспитательных задач. Рассмотрено, как в исследуемый период пропагандировался опыт использования краеведения в обучении истории.

Ключевые слова: формы обучения истории, урок, историческое краеведение, общеобразовательная школа, познавательная деятельность учащихся.

Bugrii V. S. Use of study of a particular region as means of improvement of forms of studies of history at school (30-50th XX of century).

It is set in the article, that in an investigated period there is a return in pre-revolution authoritarian «school of studies» with characteristic for it fixed form of studies form of organization of studies and subject teaching. The historical study of a particular region at school was presented by neither an independent course nor separate lessons from the study of native edge. In accordance with the decisions of party-state organs regional material could be used at the lessons of history only for illustration and specification of educational themes.

As exactly a lesson finally became firmly established in quality of basic organizational form of educational work from history, then an improvement of educational process was possible only within the limits of this form of studies. Due to the study of a particular region went her improvement. Materials about a native edge became the important element of such types of lesson, as a lesson-lecture and lesson-conversation, helping students perceive, to summarize, to master and estimate historical events.

Regional material was used not only for the decision of educational but also ideological-educator tasks to the lesson of history. Leaning on local history teachers not only diversified the fixed form of studies but also made to the students examples of courage, fight for will, social and national independence of the countrymen. Due to it not only knowledge of children were enriched about the past but also sense of pride was formed for the national belonging.

Such form of studies as lessons-excursions was widely used in an investigated period in a museum or to the historical object. She was fully built on regional basis and assisted forming of interest in an object. Especially often lessons-excursions were conducted in those schools, that were situated in regions rich on historical sights. Lessons-excursions had a large value to the regional museums, as they provided the complex study of historical event.

A study of a particular region was the important means of activation of cognitive activity of students, for this purpose teachers practiced work with evidentness, writing and archaeological to the sources. 
Key words: forms of studies of history, lesson, historical study of a particular region, general school, cognitive activity of students.

Важливим питанням розвитку сучасної школи $є$ вдосконалення методики організації навчання, вибору i застосування таких форм, які б повною мірою розкривали творчий потенціал кожної дитини, розвивали іiї здібності, сприяли б ефективній підготовці до майбутнього життя. У цьому зв'язку належна увага має приділятися історико-краєзнавчій роботі учнів, як невід'ємному складнику історичної освіти та важливому засобу підвищення якості знань, формування наукового світогляду, виховання патріотизму.

Найбільш грунтовними в галузі форм навчання $є$ дослідження А. Алексюка, Ю. Бабанського, В. Галузинського, С. Гончаренка, М. Свтуха, I. Лернера, Ю. Мальованого, О. Савченко, М. Скаткіна, М. Фіцули та ін. Сучасні підходи до методики навчання історії знайшли своє відображення в науковому доробку К. Баханова, А. Булди, Н. Гупана, О. Пометун, Т. Самоплавської, О. Удода, Г. Фреймана та ін.

У той же час аналіз літератури доводить, що сучасна педагогічна наука потребує подальшого вивчення досвіду модернізації форм навчання історії, яка здійснювалася на різних етапах розвитку вітчизняної школи.

Mema cmammi - проаналізувати практику використання краєзнавства як засобу вдосконалення форм навчання історії в школі в 30-50-ті рp. ХХ ст.

Із 1930-х рр. розпочинаються контрреформаційні процеси в радянській школі, пов'язані 3 уніфікацією системи загальної освіти. Вищим партійно-державним керівництвом видається низка нормативних документів, серед яких найбільш суттєвими були: постанова ЦК ВКП (б) «Про навчальні програми і режим у початковій та середній школі» (серпень 1932 р.), постанови ЦК ВКП (б) та РНК СРСР «Про структуру початкової та середньої школи в СРСР» (травень 1934 р.); постанови ЦК ВКП (б) та РНК СРСР «Про організацію навчальної роботи та внутрішній розпорядок в початковій, неповній середній та середній школі» (вересень 1935 р.). У цих документах декларувалося повернення до дореволюційної авторитарної «школи навчання» 3 характерними для неї класно-урочною формою та предметним викладанням. Цими постановами не передбачалося запровадження у школі ні самостійного курсу краєзнавства, ні окремих уроків з вивчення рідного краю. Допускалося використання місцевого матеріалу на уроках історії лише для ілюстрації та конкретизації навчальних тем [10, с. 59].

Виходячи з цих вимог, учителі змушені були будувати свою роботу на уроках iсторії. Опис типової для того часу методики використання краєзнавчого матеріалу, як другорядного і допоміжного, подавав педагог 3 м. Києва М. Дегтярюк: «Спочатку учитель знайомить учнів 3 конкретною історичною подією, а потім вже наводить приклади 3 місцевого матеріалу. Після цього він знов переходить до пояснення історичних подій, які мають загальнодержавне значення». Як позитив М. Дегтярюк відзначав те, що факти з місцевого історичного матеріалу збагачують уявлення учнів про минуле життя людей, їх побут, культуру, але разом 3 тим застерігав: «використовувати багато місцевого матеріалу не слід. Учитель зробить помилку, побудувавши свій урок тільки на матеріалі свого краю. Слід пам'ятати, що краєзнавчий матеріал - це тільки допоміжний матеріал, а в основі уроку повинні бути програмні матеріали» [2, с. 11].

У досліджуваний період зберігалося панування класно-урочної системи навчання, а урок остаточно ствердився як «основна організаційна форма навчальної роботи з історії» $[1$, c. 270]. Тому вдосконалення навчального процесу було можливим лише в межах цієї 
форми навчання. Перебудова уроку пов'язувалася 3 урізноманітненням його видів, активізацією пізнавальної діяльності учнів, збільшенням обсягу самостійної роботи учнів, посиленням зв'язків курсу історії з іншими предметами. Одним із найважливіших засобів перебудови уроку було краєзнавство. Матеріали про рідний край ставали важливим елементом таких видів уроку, як урок-лекція та урок-бесіда, допомагаючи учням сприймати, узагальнювати, засвоювати та оцінювати історичні події.

Багато варіантів залучення цікавого краєзнавчого матеріалу до таких уроків пропонував директор Полоцької середньої школи Жмеринського району Вінницької області О. Іванишин. Наприклад, під час вивчення теми «Велике князівство Литовське» вчитель розповідав, що Вінниччина 31362 р. входила до складу Литви. У другій половині XIV ст. Побужжя було «подароване» князям Коріатовичам. Вони на лівому березі ріки збудували дерев'яний замок - своєрідний адміністративний центр і укриття, куди збиралось навколишнє населення під час татарських наскоків. Цей замок і дав початок місту Вінниці. Учитель уточнював, що назва походить від річки Віннички, що впадає в Буг [5, с. 34-35].

Краєзнавчий матеріал допомагав цьому вчителю робити лекцію яскравою, забезпечував iii високий методичний та емоційний рівень. Наприклад, під час вивчення у 8 класі теми «Приєднання України до російської держави» О. Іванишин розповідав, як у 1654 р. відбувалася оборона м. Буші від польського війська: «Захищаючи місто від 60-тисячного шляхетського війська, населення проявило надзвичайну мужність. Коли поляки вдерлися в місто, жителі підпалили свої будинки і стали умертвляти один одного, щоб не попасти в неволю. Жінки кидали дітей в колодязі і слідом за ними кидались туди самі. Дружина вбитого сотника Зависного сіла на бочку з порохом, підпалила їі і злетіла в повітря. 70 жінок поляки затопили в печерах». Далі вчитель рекомендував дітям для читання п'єсу М. Старицького «Облога Буші» [5, с. 38].

Учитель Лозоватської середньої школи Криворізького району, Дніпропетровської області А. Кучма у свої лекції включав інформацію про топонімічні назви рідного краю і пояснював, як вони допомагають зрозуміти минуле: «У Гайдамацькій Балці $є$ печери з виходами, підземними ходами до р. Саксагані. Там було сховище від татарських орд і польських конфедератів. Сховище називалось «Гайдамацька конюшня». Це $є$ підтвердженням того, що в наших краях діяли гайдамаки, які під керівництвом свого ватажка Гната Голого боролися проти польських панів» $[3$, с. 36].

Краєзнавчий матеріал використовувався не лише для розв'язання навчальних, а й ідейно-виховних завдань уроку історії. Так, уроки-лекції про дореволюційне минуле повинні були акцентувати увагу на важких умовах існування трудового населення. Тому згаданий вище учитель А. Кучма під час вивчення теми «Розвиток капіталізму у 70-х - на початку 80-х pp. XIX ст.» наводив факти тяжкого становища робітників залізорудних підприємств рідного краю: «За 16-годинний робочий день робітник одержував від 90 коп. до 1 карб. 20 коп. Жінки, які виконували ту ж роботу, що і чоловіки, одержували ще менше - по 40-50 коп., а діти, чия праця широко використовувалась, одержували по 15-25 коп. Але навіть цих мізерних грошей робітник не одержував повністю,- частину заробітків відраховував власник під приводом всіляких штрафів. Нелюдськими були і житлові умови. Частина робітників, наприклад, на рудниках «Новоросійського товариства», які належали англійським капіталістам, жили прямо у виробках, кам'яних нішах, видовбаних у тих же кар'єрах. Там, під землею, вони працювали, їли і спали, притиснувшись до червоної брили. Печерне життя, залізна пилюка, що в 'ідалася в тіло, погане харчування і непосильна 
праця передчасно заганяли в могилу найміцніших людей» [3, с. 39-40].

Отже, учителі історії за допомогою краєзнавчого матеріалу не лише урізноманітнювали урочну форму навчання, а й наводили учням приклади мужності, боротьби за волю, соціальну і національну незалежність своїх земляків. Завдяки цьому не лише збагачувалися знання дітей про минуле, але й формувалося почуття гордості за свою національну належність.

Досить популярною серед учителів у досліджуваний період була i така форма навчання, як уроки-екскурсії до музею чи до історичного об'єкта. Вона була повністю збудована на краєзнавчій основі і сприяла формуванню інтересу до предмета. Особливо часто уроки-екскурсії проводилися в тих школах, які розташовувалися в регіонах, багатих на історичні пам'ятки. Широко практикував у своїй роботі уроки-екскурсії вчитель історії Любецької середньої школи на Чернігівщині М. Сременко. Ураховуючи, що Любеч був одним із старовинних міст України, після вивчення теми «Початок феодального роздроблення древньоруської держави» він здійснив з учнями 8 класу похід на Замкову гору - місце Любецького з’ізду князів 1097 року. 3 гори перед учнями наочно постала панорама битви 1016 року між Ярославом Мудрим i Святополком. Дітям було показано, де стояли новгородські воїни Ярослава, де знаходились війська Святополка i його союзників - печенігів. Повертаючись 3 екскурсії, восьмикласники зайшли на Любецький дитинець (Кремль), з'ясували, де обиралось місце для будівництва дитинця, де стояли стіни Кремля, склади 3 продовольством на випадок облоги, будівлі багатих жителів [4, с. 28]. Як відзначав М. Єременко, екскурсія викликала в учнів сильні емоційні переживання і надовго залишилася в пам'яті.

Велике значення мали і уроки-екскурсії до краєзнавчих музеїв, оскільки вони забезпечували комплексне вивчення історичної події. На це звертав увагу автор методичних посібників 3 краєзнавства М. Мілонов: «Головна перевага наочних посібників, представлених у музеї, полягає в тому, що вони подані не ізольовано, а в комплексі з іншими джерелами і виступають засобами розкриття змісту тієї чи іншої теми з історії даного краю у зв'язку з історією СРСР» [8, с. 77].

Задля активізації пізнавальної діяльності учнів, педагоги практикували роботу 3 наочністю, писемними та археологічними джерелами. Наприклад, учитель М. Єременко на уроці історії у 8 класі, вивчаючи тему «Культура Київської Русі», демонстрував знайдені на території свого населеного пункту буси з сердоліку і скла, скляні жіночі браслети та інші предмети XII-XIII ст. Вони служили доказом високорозвиненого ремісничого виробництва в Київській Русі [4, с. 27].

Для збільшення обсягу самостійної роботи педагоги доручали учням виконання різних краєзнавчих проектів, підготовку та обговорення доповідей на уроках, читання рефератів. Розв'язання таких завдань сприяло виробленню в учнів уміння працювати 3 багатьма джерелами. Як відзначав український методист М. Лисенко це був один із найкращих засобів активізації розумової діяльності учнів у процесі навчання, оскільки «ставив учня у становище маленького дослідника» [7, с. 42].

Добре організована ця справа була в Полоцькій середній школі Жмеринського району Вінницької області. У ній найбільш вдалі учнівські виступи і дослідження оформлялися в книзі «Визначні історичні місця краю», куди вписувався кожен новий факт, а також було створено карту таких місць. Діти намалювали схеми походів, боїв, діаграми, портрети визначних людей минулого i сучасності 3 відповідними текстовими поясненнями. Усі ці матеріали використовувалися на уроках як наочні посібники [5, с. 31].

Краєзнавство сприяло посиленню зв'язків курсу історії 3 іншими предметами. 
Пропозиціями щодо поєднання історії та літератури на основі матеріалів з історії рідного краю ділився О. Іванишин: «На уроці історії в 9 класі в темі «Кримська війна» вчитель повідомляє про те, що один 3 найславетніших героїв Севастополя - матрос Петро Маркович Кошка народився в с. Ометинцях Ситковецького району. Учитель розповідає про його героїчні вилазки в тил ворога, використовуючи при цьому книгу Сергєєва-Ценського «Севастопольская страда». У меншому обсязі цей матеріал можна використати в 4 класі в темі «Оборона Севастополя та іiі герої» і в 3 класі на уроці пояснювального читання у зв'язку з опрацюванням статті «Відважний матрос». У цій же темі в 9 класі слід ще згадати про творця польової хірургії і засновника польових госпіталів Пирогова, який останні 20 років свого життя провів у садибі Вишня (с. Шереметка, біля Вінниці). У садибі-музеї зараз зберігається забальзамоване тіло Пирогова. На уроці історії в 9 класі під час вивчення теми «Наука, література, мистецтво в боротьбі з гнітом царизму» вчитель характеристику Пушкіна доповнює матеріалами про перебування його в Україні і зокрема в Тульчині, про його зв’язок 3 декабристами. При цьому можна використати матеріали з книги Новикова «Пушкін у вигнанні», а також строфи з 10 розділу «Свгенія Онєгіна», де Пушкін згадує «пагорби Тульчина» і «степи Бугу». Про перебування Пушкіна в Тульчині слід докладно розповісти в курсі російської літератури у 8 класі під час вивчення біографії поета, а також на уроках російського літературного читання в 5, 6, 7 класах, на уроці історії в 4 класі і на уроках пояснювального читання в молодших класах, супроводжуючи розповідь читанням уривків з 10 розділу «Свгенія Онєгіна». Характеризуючи в цій же темі розвиток живопису в XIX ст., учитель вказує, що видатний російський художник Тропінін (1776-1857), будучи кріпаком поміщика Макарова, жив у с. Кукавка Яришівського району. Лише на 47 році життя він одержав «вольную». $\mathcal{C}$ дані про те, що Тропінін мав нагоду зустрічатися 3 Устимом Кармелюком. Епізод зустрічі їх описаний в романі В. Кучера «Устим Кармелюк» [5, с. 40-41].

Слід зазначити, що в досліджуваний період починає широко пропагуватися досвід використання краєзнавства в навчанні історії. Серед заходів, що сприяли пожвавленню дослідницької краєзнавчої роботи учителів, слід відзначити всеукраїнські «Педагогічні читання» викладачів історії, у які включалися доповіді з краєзнавчої тематики. Уперше вони відбулися в серпні 1953 р. в м. Одесі. Друге таке зібрання було проведено у 1957 р. у м. Дніпропетровську. У ньому взяло участь понад 700 чоловік, заслухано і обмірковано 24 доповіді. Вчителі А. Кучма (Лозоватська середня школа, Дніпропетровська область), Л. Любарова (середня школа № 7 м. Херсон), М. Рабінський (середня школа № 2 м. Богуслав, Київська область), розповіли про досвід використання краєзнавчого матеріалу на уроках історії, вміння пов'язати його 3 викладом загальних положень про закономірності історичного процесу [9, с. 74].

Отже, у 30-50-ті pp. ХX ст. відбувається повернення до дореволюційної авторитарної «школи навчання» 3 характерними для неї класно-урочною формою та предметним викладанням. Історичне краєзнавство у школі не було представлене ні самостійним курсом, ні окремими уроками з вивчення рідного краю. Відповідно до рішень партійно-державних органів краєзнавчий матеріал міг використовуватися на уроках історії лише для ілюстрації та конкретизації навчальних тем.

Оскільки саме урок остаточно ствердився в якості основної організаційної форми навчальної роботи з історії, то вдосконалення навчального процесу було можливим лише в ii межах. Краєзнавство було важливим засобом удосконалення уроку, оскільки сприяло урізноманітненню його видів, активізації пізнавальної діяльності учнів, збільшенню обсягу самостійної роботи школярів, посиленню зв'язків курсу історії 3 іншими предметами. Краєзнавчий матеріал на уроках історії використовувався для розв'язання не 
лише навчальних, а й ідейно-виховних завдань. У досліджуваний період починає широко пропагуватися досвід використання краєзнавства в навчанні історії.

\section{Література}

1. Вагин А. Основные вопросы методики преподавания истории в старших классах: [пособие для учителей] / А. Вагин, Н. Сперанская. - М. : Учпедгиз, 1959. 436 с. 2. Дегтярюк М. І. Використання наочних посібників на уроках історії: [методичний посібник з історії СРСР для викладачів 8 класів] / М. І. Дегтярюк. - К. : Радянська школа, 1955. - 108 с. 3. 3 досвіду екскурсійно-туристської та краєзнавчої роботи в школі. [зб. статей]. - Випуск 2. - К. : Рад. школа, 1957. - 79 с. 4.3 досвіду краєзнавчої роботи в школах та позашкільних установах Чернігівської області. Випуск 1. - Чернігів, 1957. 64 с. 5.3 досвіду краєзнавчої роботи в школі: [зб. статей]. - К. : Радянська школа, 1954. - 72 с. 6. 3 досвіду організації краєзнавчої роботи в школах Харківської області (Із збірок «На допомогу вчителеві»), - Випуск перший. - К. : Радянська школа, 1952. 76 с. 7. Лисенко М. Методика використання краєзнавчого матеріалу на уроках історії СРСР / Лисенко М. М. - К. : Рад. школа, 1961. - 202 с. 8. Милонов Н. П. Изучение истории области в средней школе: Из опыта работы / Н. П. Милонов. - М. : Госучпедиздат Мин. Просвещения РСФСР, 1960. - 176 с. 9. Наулко І. П. Методика викладання історії в середній школі / І. П. Наулко. - К. : Наукова думка, 1960. - 83 с. 10. Про навчальні програми та режим у початковій і середній школі. Постанова ЦК ВКП(б) від 25 серпня 1932 р. // Керівні матеріали про школу / [упоряд.: С. В. Бабич, В. О. Вікторов, С. П. Заволока]. - К. : Рад. шк., 1962. - С. 57-63.

УДК 378.091.212.2

Яна Гладир

\section{ПРОБЛЕМА ДОПРОФЕСІЙНОЇ ПІДГОТОВКИ ІНОЗЕМНИХ СТУДЕНТІВ У СУЧАСНІЙ ПЕДАГОГІЧНІЙ НАУЦІ: АНАЛІТИЧНИЙ ОГЛЯД}

Гладир Я. С. Проблема допрофесійної підготовки іноземних студентів у сучасній педагогічній науці: аналітичний огляд.

У статті здійснено аналітичний огляд концептуальних педагогічних праць останніх 15 років, присвячених проблемам допрофесійної підготовки іноземних студентів, визначено стан розробки проблеми в межах спеціальності «Теорія та методика професійної освіти». Приділено увагу й невітчизняним педагогічним дослідженням цього ж періоду, теоретичні концепти яких використовуються українськими науковцями.

Ключові слова: допрофесійна підготовка, іноземні студенти, дисертаційні дослідження, аналітичний огляд

Гладырь Я. С. Проблема допрофессиональной подготовки иностранных студентов в современной педагогике: аналитический обзор.

В статье сделан аналитический обзор концептуальных педагогических работ последних 15 лет, посвященных проблемам допрофессиональной подготовки иностранных студентов, обозначено состояние разработки этой научной проблемы в границах специальности «Теория и методика профессионального образования». Внимание уделяется и неотечественным исследованиям этого же периода, теоретические концепты которых используются украинскими учеными.

Ключевые слова: допрофессиональная подготовка, иностранные студенты, диссертационные исследования, аналитический обзор 